\title{
Victimhood Olympics
}

In January 2020, the Russian-language bimonthly "Russia in Global Affairs" published an article on "memory politics" and related conflicts, following a roundtable hosted by the magazine (Rossiya, 2020). To our amazement, the discussion caused a very keen reaction, especially in Europe. Our modest publication was immediately dubbed as nearly a forge of Kremlin ideas regarding "memory wars," which, of course, is flattering, but, alas, is not true.

In general, the willingness to see behind everything a conspiracy of dark forces and the belief that everything happens for a reason, well-known to us from our own history, have now spectacularly become commonplace. So, since the topic triggered such a powerful response, we decided to take it further by asking members of the academic community in different countries how they assess the current state of affairs in "memory politics." They came up with a very broad range of opinions, which we gladly share with our readers. ${ }^{1}$

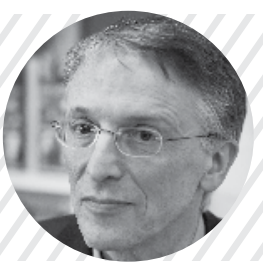

\section{Yuri Slezkine}

Professor of History, Director of the Institute of Slavic, East European, and Eurasian Studies at the University of California, Berkeley, USA.

All human communities mythologize their past. Regime change requires pantheons to be reinvented. In the search for the meaning of its post-Soviet existence, the reformed West (also known as the "international community") needs a new genealogy. And it is building several of them at once.

First published in Russian in Rossiya v Globalnoi Politike, 18(2), 2020, under the title of "Olimpiada Zhertv Istoricheskoi Nespravedlivosti" ("Olympics of the Victims of Historical Injustice"), on March 5, 2020. 
The place that was occupied by "the Christian world" and its successors"the civilized world," "the free world," and "the Western civilization"-is temporarily empty after their decline. The promotion of democracy and the struggle for human rights did not last long. Traditional military-political, financial, and intellectual centers are rapidly advancing the culture of collective repentance for the sins of privileged groups, successful states and the entire Christian/civilized/free world, a culture originally devised in Germany and quite unprecedented in memory politics. Meanwhile new members of the community are actively furthering the Old Testament tradition of Babylonian-Egyptian capture, thus undermining the longstanding monopoly of the Holocaust. Russia with its Great Victory in World War II is an anachronism for some, a well-timed threat (to the future, the present and the past) for others, and a structural antipode for most others.

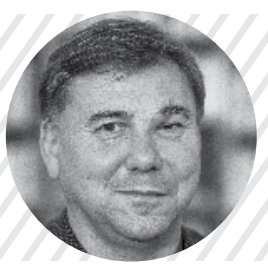

\section{Ivan Krastev}

Chairman of the Centre for Liberal Strategies, Sofia, Bulgaria, and Permanent Fellow at the IWM, Institute of Human Sciences in Vienna, Austria.

Today in Europe we live in the Age of Nostalgia. The majority of Europeans believe that life was better before, with "before" remaining unclear. The logical consequence of our nostalgic mood is that the most critical question is not who will own the future but who was right in the past. The Post-Cold War European attempt at pan-European reconciliation has failed.

In the days of the classical nation-state, identity-building was very much centered on building the sense of common victimhood. "We, the nation" meant "we, the victims." The European Union's post-1989 ambition was to radically change this, and "we, the nation" began to mean "we, the perpetrators." In the post-1989 world memory politics was the politics of forgiveness. Poles and Romanians were forced to face the truth about the rise of anti-Semitism in their countries in the pre-war and war periods. Bulgarians were forced to recognize the crimes committed by the communist government against Bulgarian Turks in the 1980s. Russians were forced to answer for Stalin's crimes. 
Now we are back to the Victimhood Olympics. European nations feverishly compete to prove that they are the biggest victim of historical injustice. What is really troubling is that the real prize one gets for winning the Victimhood Olympics is the privilege to act as a villain.

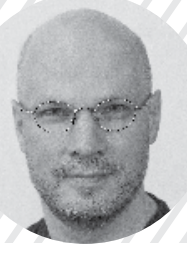

\section{Martin Aust}

Professor of History and Culture of Eastern Europe at the Rheinische Friedrich-Wilhelms-Universität, Bonn, Germany.

While preparing a lecture on entangled memory cultures across Germany, Eastern Europe, and Russia back in 2010 at LMU Munich, I first came across the term 'memory wars.' Deeply rooted in the German culture of reconciliation and sharing histories as a means of understanding and rapprochement, I was irritated by that term. To be sure, I was well aware that basically politics, the arts and academia each treat history in their own way: for purposes of forming political agendas or underwriting concepts of identity, for creating an artwork, be it a novel or a film, or for developing a scholarly view of the past formed by academic methodology. Furthermore, I believed in the public as a sphere which allows academic readings of the past to make an argument with uses of the past in politics and the arts. To put it in a nutshell: I believed that under liberal and democratic circumstances scholarly knowledge would ultimately hold sway over political uses and abuses of the past in an enlightened and cosmopolitan public sphere.

Against that background the term 'memory war' appeared to me as too dark an assessment of the state of memory culture. What about encouraging examples of dialogue over the past decades? I was focusing on events which seemed to underscore my perception of memory culture as a means of coming together and overcoming conflicts: in 1997, Polish and Ukrainian Presidents Kwaśniewski and Kuchma signed a document of Polish-Ukrainian reconciliation. In 1999, Jerzy Hoffman's film “Ogniem i Mieczem” (With Fire and Sword) reached out to display the Khmel'nyts'kyi uprising of 1648-a topic which had pitted Ukrainians against Poles for centuries-in a way that put the two nations on a par with each other. Indeed, the film was positively received in Ukraine at that time. In 2010, Russian and Polish Prime Ministers 
Putin and Tusk met in Katyń to commemorate the Polish victims of NKVD mass shootings in 1940. Also in 2010, the Polish-Russian volume White Spots, Black Spots addressed difficult issues in Polish-Russian relations in the 20th century. In Germany, Erika Steinbach's initiative in 1999 to move Germans who were expelled from Eastern Europe in 1945-1946 into the focus of German memory culture was met by founding the European network Memory and Solidarity. Although the Czech Republic rather soon exited the initiative, it united Germans, Austrians, Poles, Slovaks, and Hungarians to further elaborate a shared memory of expulsions. All in all, in my eyes the glass seemed to be half full, not half empty.

These days I have to realize that over the past years the politics of history have indeed become a thorny issue full of controversies and antagonisms. Memory culture has transformed from cosmopolitan to antagonistic. Actors of the politics of history urge others to accept their reading of history, most often encased within a national frame of the past. History laws and anniversaries are cases in point which show politicians across the board from the EU over Poland, and Ukraine to Russia hijacking the interpretation of the past for ultimately political purposes.

From 2009 to 2012 Russia had a presidential commission to fight what the government perceived as falsification of history. It served the purpose of stressing the Soviet Union's contribution to the victory over Nazism in Europe. In 2015, Ukraine passed memory laws which call for disentangling the Ukrainian past from Soviet history and for starting a process of overall decommunization by renaming streets and toppling monuments to Soviet figures. In 2018, Poland passed a law which threatened to punish anybody implicating collaboration of the Polish nation in the Holocaust. With the law coming under criticism both in Poland and Israel, Poland eliminated penalties from the bill.

Last year, the 80th anniversary of the Molotov-Ribbentrop Pact, also known as the Hitler-Stalin Pact, raised the stakes in the politics of history. On September 18, 2019, the European Parliament passed a declaration on the importance of European remembrance for the future of Europe. Some issues of the resolution cannot but draw criticism from historiography. The resolution claims that the Hitler-Stalin Pact ultimately paved the way for the outbreak of the Second World War and thus implicates Germany and the 
Soviet Union on equal terms in starting the war. From a chronological angle that is most obvious. Within just a week after signing the treaty Poland was attacked by Germany, with Hitler being reassured that this step was made in accord with Stalin's views. However, with regard to a broader genesis of the war German and Soviet diplomacy and the guiding principles of Hitler and Stalin paint a more complex picture which is not captured by the European Parliament's resolution. Ever since taking office as Reichskanzler back in 1933 Hitler wanted that war. Hitler's path to war first with Poland and then with the Soviet Union was chartered by three imperative principles: to undo the Versailles order, to fight Bolshevism, and to annihilate Jews. Stalin's foreign policy was determined both by ideology and pragmatism of great power politics. In 1938, Stalin had to learn the lesson that without consulting the Soviet Union the Western powers let Hitler have his way. So, in 1939 Stalin decided to cooperate with Hitler. Even without Stalin's consent Hitler would have done everything possible to start the war he had always wanted.

Another flaw of the resolution is the renaissance of the term 'totalitarianism.' To be sure, both Nazi Germany and Stalin's Soviet Union committed mass atrocities on a large scale. However, to group both under the umbrella term of totalitarianism only works with regard to the abstractions of the history of ideas. From that point of view, Nazism and Stalinism were dictatorships which used mass violence to shape societies according to their ideological visions of the future. Beyond that, the comparison between Nazism and Stalinism displays so many differences between these two regimes that the term 'totalitarianism' obfuscates the past. From 1933 to 1945 there was an ever-growing process of German violence unfolding. Violence in Stalin's Soviet Union was a sequence of mass terror ordered or halted by Stalin. Hitler gave his orders only by way of verbal communication. Stalin sat in the Kremlin reading acts and personally signing orders of mass murder. After the so called Röhmputsch in 1934, the Nazis never ever again turned their terror against their peers. In Stalin's Soviet Union members of the Communist party were not in a safe haven which protected them from falling victim to Stalin's terror. Germans committed the Holocaust, Soviet troops freed Auschwitz. The Nazi system did not survive the death of its leader, the Soviet system did that a couple 
of times. The comparative history of Nazi Germany and Stalin's Soviet Union can only be written beyond totalitarianism as Sheila Fitzpatrick and Michael Geyer once put it in editing a volume on the two dictatorships.

Instead of leaving it to historians to mark the weak points of the European Parliament's declaration, Russian President Putin dared to assume the role of a historian. On December 20, 2019, at an informal CIS summit Putin lectured his colleagues on the beginning of the Second World War. In a roundtable lecture with his presidential colleagues he dived into archival documents to examine the European Parliament's resolution. According to historian Putin's findings, Poland was implicated in the outbreak of the Second World War. Putin enlisted all bilateral treaties Nazi Germany had signed with other states, among them Poland, in 1934 to conclude that the Molotov-Ribbentrop Pact only continued the common European practice. That point of view misses the fact that the treaties other states had signed with Nazi Germany were not accompanied by secret protocols to invade and partition neighboring countries which sets the Molotov-Ribbentrop Pact clearly apart from these other treaties.

The 75th anniversary of the liberation of Auschwitz on January 27, 2020 showed that the antagonistic politics of history continued. In Jerusalem and Auschwitz commemorations were held, which reflected the strained state of affairs between Poland and Russia. Polish President Duda refrained from visiting the commemoration in Jerusalem organized by the World Holocaust Forum as he did not want to be forced to listen to another history lecture by Putin who was one of the main speakers at the event. In terms of antagonistic politics of history it came as no surprise that Putin was not among the guests at the commemoration ceremony in Auschwitz. The 75th anniversary of the end of the Second World War in Europe on May 8/9, 2020 will probably once more illustrate how commemorating the war and its end rather splits than unites the U.S., Europe, and Russia.

All this might have serious repercussions on German memory culture. With the German government and parliament moving to Berlin in 1999 and the early zero years of the 21st century, German symbolic commemoration culture in the center of Berlin took shape: the Holocaust memorial, the monument to Sinti and Roma, a monument to oppressed homosexuals and another monument to the victims of euthanasia were erected. Critics rightly 
pointed out that there is a blank spot: there is no monument to the victims of Germany's war of annihilation first in Poland and then in the Baltic countries and the Soviet Union. Initiatives have advanced proposals to do something about that. In 2013, the founder of the German-Russian Museum Berlin-Karlshorst, Peter Jahn, proposed to create a memorial to the victims of Nazi Lebensraum policy in Poland and the Soviet Union. In 2017, Florian Mausbach issued a call to erect a monument to murdered Poles. Also in 2017, invited by the Greens in the German Bundestag, historian Timothy Snyder recommended that in commemorating the victims of the Second World War Germany should put Ukrainian victims first since-so Snyder against the historical record-Ukraine was the most important war aim of Germany and had to suffer the most.

These initiatives have reached the German Bundestag. There is a multiparty call by members from all parties with the exception of the Alternative for Germany to build a monument to Polish victims of Germany's war of annihilation. At the same time, the parliamentary group of the Social Democrats argues to establish a documentary center to commemorate all victims of Germany's war of annihilation across Eastern Europe and the Soviet Union. The Foundation Memorial to the Murdered Jews of Europe yet came up with a third proposal, namely, to establish a documentary center of German occupation and atrocities across all of Europe including the Soviet Union.

At the moment, it seems that neither of these initiatives has a majority in parliament. The big question is whether there could be a road on which these initiatives might join forces. From the point of view of historiography and memory culture such a compromise can be brokered. It would not be easy to design such a compromise, but it is also not impossible. However, this is where history wars between Russia, Ukraine, Poland, and the European Parliament backfire on the German debate. Among the proponents of a monument to Polish victims there are some voices which use Putin's history lecture to claim that there could not be a shared commemoration of Polish and Soviet victims in Germany. So, in the end there is no alternative to joining Pavel Polian's recent plea in an interview with the TV channel Dozhd: Please leave history to historians, do not turn history into a political weapon. The politics of deescalating memory wars has to be reinvented. 
Historians should take the lead in doing that by raising their voices in favor of careful studies of the complexities of the past.

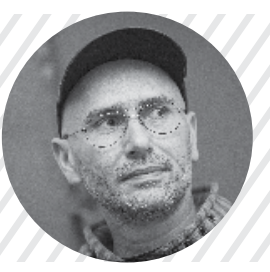

\section{Jan Sowa}

Faculty member, Academy of Fine Arts in Warsaw, Poland.

Memory politics is a tool devised to achieve contemporary political goals by creating ideologically distorted narratives about the past. In contemporary Poland it is mainly a domain of right-wing forces-from populist to conservatives to neo-fascists-however it was also used by other political formations. The goals of the right-wing memory politics fall mostly in two categories: legitimizing political goals by invented tradition and seeking national recognition.

When it comes to legitimacy the trick is to construct an artificial version of Polish social and cultural history that would prop up the right-wing goal of keeping Poland homogenously white and Catholic. It is an incredible irony that such a Poland is only a product of deliberate and ruthless social engineering undertaken by Hitler and Stalin in mid-twentieth century (exterminating Jews, Gypsies and other minorities followed by massive population displacements after 1945). In 1939, one third of Polish citizens was neither ethnically Polish nor Catholic-a degree of heterogeneity higher than it is the case in many of the contemporary Western societies that are allegedly "overwhelmed by aliens" as the right-wing groups maintains. Wiping out minorities from collective memory creates a fake Poland and "Polish tradition" that is supposed to have existed since the long-gone past and that is employed to normalize xenophobia and nationalism as a "rightful defense of our traditional way of life."

The game of recognition is more complicated. With a growing economy more and more Poles find out that what they are mostly lacking is not money nor material wealth but a feeling of national pride and recognition. We are the EU's fifth largest country with a truly imperial past, however our image in the West oscillates between a source of cheap labor and a black hole 
where stolen cars disappear. Right-wing groups have correctly observed that contemporary politics of recognition is mainly an Olympics of victimhood and it fits very well into their libidinal framework-after all Poland has always been one big victim in the eyes of Polish patriots. The Swedish invasion and Ukrainian revolts in the 17th century, foreign intrigues in the 18th century, partitions in the 19th century, and Soviet domination preceded by horrors of the Second World War in the 20th century-every pupil knows by the time he is in the 5th grade that Poland would have been the greatest of all world empires if it had not been for that mischievous machinations of our evil enemies, mostly Russians and Germans. The Second World War plays a key role in that narration as it is a relatively recent event, it went in its scope far beyond Polish borders, it featured Germans in the role of the main villain and it truly brought incredible havoc to Polish society (Poland was, materially, the most devastated country after the Second World War). This provides a perfect opportunity to present to the world our suffering and heroism.

There are, however, two obstacles. The first one is the Jews. Not only did they suffer enormously during the war, but it is also widely known and often repeated that they were persecuted by Poles who on many occasions found it at least handy to have Germans get rid of that much hated group. Thus, in the eyes of the Polish right the Jews are stealing our enjoyment and taking the place of the main victim of the war, not allowing us to fully articulate our own suffering. The second problematic group is the Russians. While it is true that Stalin made a pact with Hitler who invaded Poland in 1939, it is equally true that the Red Army was a key player in defeating the Nazis and that Soviet society paid a dear human price for that achievement. The Polish right believe that celebrating the latter instead of condemning the former is not only historically and ethically wrong, but also very damaging to our struggle for recognition as it obfuscates our victimhood and eclipses our heroism. So the goal of the Polish right-wing memory politics is to diminish the role of the USSR in defeating Hitler while exposing the barbarism of the Red Army (Katyń, looting and rapes as a prelude to the Soviet occupation after the war) - the agenda that is directly the opposite of the memory politics undertaken by Putin. A clash seems inevitable. 


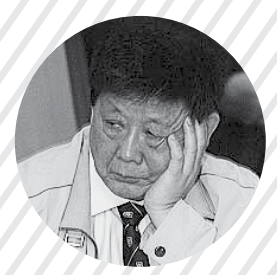

Wu Enyuan

PhD in History, former head of the Institute of World History of the Chinese Academy of Social Sciences and the Institute for Russian, Eastern Europen and Central Asian Studies of the Chinese Academy of Social Sciences, China.

The past few years have seen an increasingly growing tendency to reassess the history of World War II. Attempts have been made to overturn the conclusions that have long become universally accepted. It is claimed that the war was started not by fascist Germany, but by the socialist Soviet Union; that Stalin is not the liberator of Eastern Europen states, but their invader. "National traitors" who helped Hitler resist the Red Army in those years are called "national heroes..." Ideological trends that can be called "historical nihilism" exist not only in Europe, but also in Asia: they do not recognize the Cairo (of 1943, stating the goals of the war with Japan-Ed.) and the Potsdam Declarations, refuse to return to China the Diaoyu Islands occupied by Japanese aggressors, and so on.

Historical revisionism is a widespread phenomenon. However, it should be noted that most of those who promote such judgments are not scholars, but government officials. This only proves that they are not seeking truth but are acting solely for political purposes. The development of human civilization has already proved that the falsification of history, based on political intentions, has no chance of success. This is precisely what World War II hero Stalin said: "I know that after my death a pile of rubbish will be heaped on my grave, but the wind of History will sooner or later sweep it away without mercy."

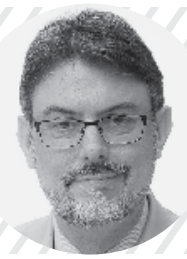
Anatol Lieven
Professor, Georgetown University in Qatar, Senior Fellow
of the New America Foundation in Washington.

A very curious feature of "progressive" culture in Europe and the USA today is the combination of endless apologies for past sins of Western racism, imperialism and so on with arrogant ideological superiority towards the 
rest of the world, and towards benighted (white) conservative elements of Western societies. It seems a bit like the old Catholic practice of Indulgences: a ritual act of apology makes you good and pure again, and therefore in a position to look down on and dictate to those who have not yet adequately apologized for their sins.

Tony Blair represents an extreme form of this attitude, or pathology. None of his apologies for British imperial crimes led him to wonder for a single second whether this record might give people good reason to doubt Britain's honesty, intentions and capabilities in helping the USA to invade Iraq in the name of freedom, peace and democracy. The French progressive intelligentsia is another example. Having abandoned socialism, but being quite incapable of abandoning a sense of individual and national civilizing mission, they have made a cult of preaching human rights to the rest of humanity, a mission that is not at all qualified by their acknowledgement of monstrous past French crimes.

Associated with this are aspects of the widespread cult of victimhood. This psychological shift from legitimate sympathy for victims to compulsory admiration for victims stems partly from a sort of international competition to suggest comparisons between your own collective sufferings and those of the European Jews during the Holocaust; and partly from the demilitarization (dare I say feminization?) of broad swathes of Western culture, especially in academia and the media.

Thus, in sympathizing (quite rightly) with the sufferings of colonized peoples, it has become distinctly unfashionable and frowned-upon to recognize-and respect-the fact that Zulus, Chechens or Afghans were not simply victims, but also tough and courageous warriors fighting in defense of their own traditional orders and values - which were most assuredly not those of contemporary Western liberalism.

In the teaching of the Second World War, this approach contributes to a wider tendency (fueled by state propaganda campaigns by particular NATO and EU states) to cast the Soviet Union as an enemy and not an ally of the West, analogous to Nazi Germany. On the one hand, the great reduction in attention paid to the battles and the soldiers who fought in them means a great reduction in recognition of the Soviet soldiers who did the great majority of the fighting. On the other hand, the indiscriminate mixing of 
Nazi crimes, Soviet crimes and collaborationist crimes creates a historical fog out of which-Hey Presto!- - the Western progressive tradition shines once more pure and unsullied.

If there is one book that I would make compulsory reading in any course about the Second World War, it would be Vassily Grossman's Life and Fate: a profound meditation on the analogous evils of the Nazi and Stalinist systems that on the other hand does not doubt for a second the justice of the Soviet War, and also praises the idealism of many Communists (however misplaced); and a work of the deepest sympathy for the victims of the war that at the same time celebrates the heroic endurance of the defenders of Stalingrad and their vital role in the salvation of Europe.

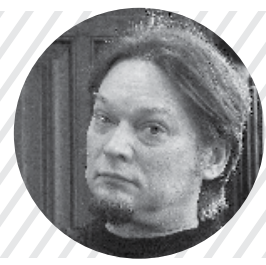

\section{Sergey Ushakin}

Professor of Anthropology and Slavic Studies,

Princeton University, USA

"Historical revisionism" is a normal thing. Not in the sense that it is good and nice, but in the sense that almost every generation that becomes fullfledged sooner or later begins to formulate for itself a history with which it could and would like to live. Such revisionism is not necessarily associated with World War II. Occasional heated debates on how to remember the 1990s are an example. The logic of all revisionisms is similar and boils down essentially to a simple idea: let me believe in my own version of the past. The peculiarity of the current situation is the surprisingly fast normalization of what used to be called "social order," and now is called "public history," that is, the conscious use of historical material to achieve goals that are not directly related to history.

In one of my seminars, my students read a study on how the decision was made to create the Holocaust Memorial Museum in Washington in the 1990s. Two museum schools were fighting at that time. The supporters of one position said: Let's make it a real museum, with documents, artifacts and studies that will show what happened, when, where, and how. They were opposed by another group, which insisted that details and other historical 
artifacts were important and necessary, but the main thing was to form a special attitude towards the Holocaust among visitors, to offer them a "scenario" so that they could feel all the horror of those events.

In other words, while the first group defended history as a factual account of events, the second group preferred to focus on historical drama, with a characteristic propensity for theatricalization of history. The school of "historical playwrights" won, and Ralph Appelbaum's museum design company began its triumphant march around the world, including Russia where the same experts, guided by the same principles, created an exhibition at the Jewish Museum and the Tolerance Center in Moscow and at the Yeltsin Center in Yekaterinburg. History has become a chance to get an emotional experience.

The current revisionism was largely brought into existence by this important shift in the understanding of the usefulness of historical narratives for the emotional mobilization of audiences. I once called this approach "affective history management": the fundamental importance of historical material in this case lies not so much in its plausibility, as in its ability to cause a strong response (positive or negative). Actually, this is exactly what we all saw in the recent squabble over the anniversary of the liberation of Auschwitz. After all, the sides were defending by and large not historical truth, but their own dignity.

Clearly, there are many reasons for such actualization of history. One of them is the fact that in Russia the idea of an abrupt break with the Soviet past is being gradually replaced by calmer attempts to build a certain line of continuity. Judging from the historical exhibitions I visited (unlike books, exhibitions can respond to changes more quickly), one can see how the "Soviet" period is increasingly often interpreted as part of longer trends such as urbanization, modernization, industrialization, the improvement of everyday life, and the like.

Our former "socialist camp brothers" stick to a fundamentally different logic: the recent past is perceived as a source of possible, but (as a rule) failed histories of national independence or struggle for it. "Soviet" in this case appears to be an obstacle, a dead-end, and a barrier on the way to sovereignty.

Clearly, these two historical logics are hardly compatible. What is considered modernism in Russia appears to be very similar to cultural 
imperialism in Belarus and Kyrgyzstan. This anti-colonial trend, which is often perceived as anti-Russian, will keep growing.

Who is "to blame" here is quite clear. What is to be done is what is important. Conditional "Poles" are "redrawing" the historical narrative not because they want to hurt their "big eastern neighbor" one more time. This is happening because they do consider their version of history correct, that is, corresponding to their view of the world and their place in this world. It is more difficult to talk about such confidence in Russia-hence the nervousness about the change of narratives.

In a recent outburst of emotions over the notorious "anti-Semitic pig" remark, what is alarming is that facts became public so suddenly, even though the documents had been there all the while and sometimes, as in this particular case, even known. The general concern about one's own history grows out of this tactical attitude to historical sources. It is good that the Ministry of Defense publishes archival documents by a certain historical date. What is bad is that they were not made available before. Or another example: try to find materials about the Chechen War in the Boris Yeltsin Presidential Library. I have tried. The latest archival materials date back to 1937 (the earliest, by the way, to 1802). Where are the fresher ones? Which "out-of-range zone" are they in now? And for what reason will they suddenly be made available?

You cannot be sure of your history, bad or good, knowing that somewhere there are kilometers of shelves holding documents that are inaccessible to researchers. Strength, as we remember from a well-known film, is in truth, and truth is in sources.

I would make the next ten years in Russia a decade of archival revolution to digitize and publish everything that relates to the Soviet period. And I would also provide 150-200 grants annually for the study of problems in Soviet history. Not everything will work out well at once. But it takes a good broth to cook a good soup. We have seen recently how electronic availability of historical documents radically changes the attitude towards history. For example, the Prozhito (Lived Through) (https://prozhito.org/) website team, which collects and publishes personal diaries, has basically created a new discipline and a new community from scratch, allowing everyone to see how ordinary people from different times "formulated" life in their own 
words. Or here is a completely different example. Without the generalized Memorial data bank, there would be no mass Immortal Regiment movement. There can be many examples, but the overall effect is important: historical information directly available to any user changes not only the attitude to history but makes history a part of people's daily life. The openness of sources rids history of exaltation and strain which are constantly fueled by suspicions, fears or hopes that we do not know the whole history, unlike some people...

Every two weeks I receive e-mail newsletters from the U.S. National Security Archive (https://nsarchive.gwu.edu/postings/all). Usually they inform me of declassified documents and give links to their electronic copies on the archive's website. The recent news that the CIA watched 120 governments for many years thanks to the purchase of a Swiss encryption company is based on publications from this archive. A week earlier, the archive published a compilation of U.S. intelligence activities to undermine the Soviet missile program in the 1950s. News and documents differ, but the approach is the same: all historical news is worth publishing. I think this rule should become the starting point. Otherwise, we will not be able to break this vicious circle, in which revisionism generates a reaction, and the reaction causes another attack of revisionism.

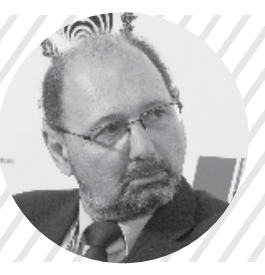

\section{Richard Sakwa}

Professor of Russian and European Politics, University of Kent, UK.

In the summer of 1939, my father was serving as a reservist in the Polish Army, and his unit was pushed eastward by the German advance after September 1. In the days after September 17, he encountered the Soviet forces, which were welcomed at first as having come to help the fight against the Nazis. However, when asked to give up their weapons, they understood that an entirely different logic was in play. Many of the reservists went on to perish in Katyn and other execution camps, while my father managed to escape. After internment in Hungary and many adventures traveling through 
Romania and Yugoslavia, he joined the Polish Second Corp under General Anders in Egypt, and together with the British Eighth Army fought at El Alamein, Sicily, Monte Cassino and all the way up in Italy. Unable to return to Poland after the war he found refuge in the UK, and finally found rest in the Kensington and Chelsea Cemetery in Gunnersbury, 50 meters from the Katyn Memorial.

If anyone should have been inspired by the spirit of grievance and revenge, it was him, but he never was. This was also the case with most first-generation Poles living in West London, many of whom had been exiled to Central Asia, and made their way to England via Persia and Palestine. Thus, they lived in a spirit of forbearance, and sometimes even forgiveness, unlike that of the nation as a whole. The Copenhagen criteria of June 2003 stipulated three conditions for European Union membership: whether a country had the institutions to preserve democratic governance and human rights; a functioning market economy; and acceptance of the obligations and intent of the EU. At that time perhaps a fourth point should have been made explicit-that the EU was not a forum for the amplification of historical grievances, but a place for them to be overcome. Instead, after the "big bang" enlargement of 2004, in various ways and over various time scales, the question of history has gained ever greater prominence. While the EU was a profound and transformative instrument for reconciliation between its original members, one of the fundamental unfulfilled promises of 1989 is the failure to generalize this experience to the whole of Europe, from Lisbon to Vladivostok, in the post-communist era.

This brings us on to the question of Russophobia. The term is quite rightly sometimes dismissed as an easy way for Moscow to shrug off legitimate questions about its past and present, but the term raises issues far deeper than that. This aspect of memory politics lies at the intersection of values and identity. As Hermann Goering put it in conversation with Polish Marshal Edward Rydz-Śmigły on 16 February 1937, "the danger is not only Bolshevism, but also Russia itself, regardless of whether it has a monarchical, liberal or other system." It is quite legitimate for the EU and other like-minded institutions to advance a normative agenda, but when these become bound up with identity issues, then we are on slippery terrain. The specificity of the historical and even civilizational experience 
of others can be negated in pursuit of an imposed version of the truth. It is out of this nexus that Russophobia grows, and with it a whole new cycle of conflict and confrontation. This, in turn, gives rise to mnemonic battles, with struggles over the existence, nature and relevance of the past. Because of the imperfect and ultimately self-serving character of the post-1989 settlement, mnemonic wars will shape the forthcoming period of European history. The struggle over ideology has given way to a battle over meaning.

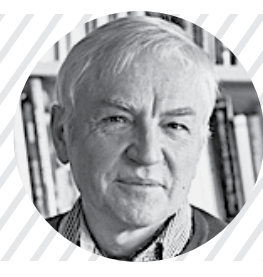

\section{Pål Kolstø}

Professor, ILOS Department, University of Oslo, Norway.

It has been said that Eastern Europe suffers from an overload of history. In fact, the problem is not history as such — which all regions in the world have in equal measure-but the intense politicization of history. This reached a high watermark this winter when Russian President Vladimir Putin and Polish Prime Minister Mateusz Morawiecki accused each other of distorting the truth about the outbreak of World War II.

At a meeting of CIS heads of state on December 20,2019, Putin put forward the remarkable accusation that Poland was partially responsible for unleashing that world conflagration, claiming that, prior to the outbreak of the war, Polish leaders had "pursued mercenary and exorbitantly overgrown ambitions, laid their people, the Polish people, open to attack from Germany's military machine, and, moreover, generally contributed to the beginning of the Second World War" (Putin, 2019). This had all the hallmarks of blaming the victim. Moreover, it was not a sudden outburst of anger, but a well-prepared and lengthy exposé.

This attack did not come out of the blue. It was triggered by a resolution of the European Parliament three months earlier, adopted at the instigation of the Polish government, on the "Importance of European Remembrance for the Future of Europe" (Resolution, 2019). The resolution asserted that not the Poles but the Soviets had acted as Hitler's accomplices and unleashed World War II. “The most devastating war in Europe's history was started as 
an immediate result of the notorious August 1939 Nazi-Soviet treaty on nonaggression and its secret protocols." Putin's December broadside against Poland was a classic tit for tat.

Historians who have taken the effort to fact-check Putin's speech have concluded that all the documents he referred to are genuine and well known to historians (Radchenko, 2020). But while he had all the quotations right, he was also guilty of "gross omissions" and historical "cherry picking" (Desai, 2020). Some of those cherries, however, were rather big, and have been left out of the standard Polish and most Western narratives. Specifically, this is the case with the centerpiece of Putin's litany of Polish iniquities, that Poland took part in the dismemberment of Czechoslovakia in October 1938: parallel with Hitler's occupation of Sudetenland, the Poles helped themselves to a slice of Czechoslovak territory in Upper Silesia known as Teschen (Český Těšín or Cieszyn), while the Hungarians annexed southern Slovakia and southern Ruthenia. To be sure, the Polish piece of the cake was small compared to many other land-grabs in Europe at the time-but the justification for it and the willingness to collaborate with a totalitarian power in order to achieve territorial enlargement was the same.

By reminding his audience about the dismemberment of Czechoslovakia in 1938, Putin sought to deflect attention from how the German and Soviet dictators gobbled up Poland the year after. This was no doubt a "whataboutism," but in my view, it is often quite legitimate to ask "What about...?" While that can be used as a strategy to trivialize one's own transgressions, it may also place events in historical perspective. On the other hand, when one compares one's own actions to those of others in order to highlight the similarities, one must also accept that others may point out the differences. And commentators have remarked that while European history in the interwar period was indeed awash with "nonaggression pacts," also with Hitler, the Ribbentrop-Molotov pact uniquely included secret protocols that gave Germany and the Soviet Union carte blanche to divide Eastern Europe brazenly into "spheres of influence." ${ }^{\text {2 }}$ But again, for the sake of historical completeness, we may add another "whataboutism":

$2 \quad$ Putin intimated that also some other accords with Hitler may have contained nefarious secret appendices, unknown to us today because they are still locked up in the archives, but this argument remains pure speculation and carries little weight. 
What about Winston Churchill's proposal to Stalin in October 1944 to divide Eastern Europe into a Soviet-influenced and a Western-influenced part-a proposal that, it is true, never became a formal agreement, but which disconcertingly anticipated the contours of the later Iron Curtain?

Today, in neither Russia nor Poland are the authorities prepared to engage in what Germans call Vergangenheitsbewältigung ("facing up to the past"). At one point, under "the Medvedev thaw," both Dmitry Medvedev and Vladimir Putin adopted a surprisingly critical attitude towards the crimes of the Stalinist regime, with Putin in April 2010 commemorating the massacre of Polish officers in the Katyń forest together with Polish Prime Minister Donald Tusk, but that seems now to be bygone times (Kolstø, 2019).

Why then should Putin feel obliged to defend the honor of Stalin? The short answer is that the current Russian leadership has no particular interest in whitewashing Stalin or his henchmen (there are other forces in Russian society today ready to do that), but the memory of the sufferings and triumphs in World War II is quite another matter: that memory is a cornerstone of national consolidation. The Great October Revolution, once the main legitimization plank of the regime, has been debunked. As respected Russian sociologist Lev Gudkov has argued, the Russian nation today is riven by ideological tensions between Stalinists, liberals and Putinists; and commemoration of the victory over Nazism "remains the only opportunity for the nation to assert itself. There are no other foundations left for national pride" (VOAnews, 2015). The Kremlin cannot allow anyone to besmirch the sacred memory of the Victory, and Stalin played a crucial role in that feat.

In Europe today, several states, among them Russia, Poland, Hungary, and the Czech Republic, have adopted very similar domestic policies marked by conservativism, neo-traditionalism and trenchant illiberalism. In Hungary and the Czech Republic, these ideological affinities have led to cozy relations between their leaders and the Kremlin. Not so in Poland: bad historical memories intervene. This is nothing new, but the ferocity of the altercations-and particularly the recent Russian claim that Poland contributed to the outbreak of the war-certainly is. If this was intended as an attempt to sway international opinion, Putin seems to have overplayed his hand. 


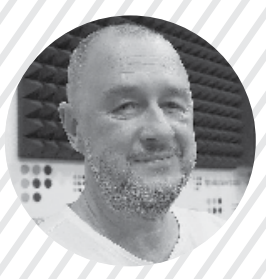

Georgy Kasyanov

PhD in History, Professor, Head of the Department of

Modern History and Politics at the Institute of History of

Ukraine of the National Academy of Sciences of Ukraine,

Kiev, Ukraine.

The old idea that foreign policy is a continuation of domestic policy remains relevant. The fact that discussions about the past have so dramatically turned into public scandals, going all the way up to the top political leadership, did not come out of the blue or for no reason.

This is a long story that began almost 15 years ago, when the countries of the former socialist bloc conjunctively joined NATO and the European Union. The political and cultural elites of these countries, guided by rather utilitarian considerations, promoted the image of their nations as double victims of Nazism and communism. This was a direct challenge to Russia's ruling class, for which the Red Army's liberation campaign was an important part of the systemic myth about the victory in the Great Patriotic War as an unprecedented feat of saving Europe. This myth performed and still performs an extremely important socio-cultural and political function: ensuring certain spiritual unity of the community that is represented as the "Russian nation"—it is a common victory for all citizens of Russia, regardless of ethnic or cultural background. Claims that the liberation of Europe (we all know which Europe is meant) was actually new occupation, perhaps even worse than the Nazi one, is a direct challenge not only to Russia's foreign policy prestige and geopolitical influence, but also to the central idea that ensures internal unity. The depreciation of the founding myth about the liberating army and its replacement with a myth about the occupying army rocks the foundations of modern Russian statehood.

In turn, the actions of Russia's top political leadership to deconstruct the myth about a double victim and its remarks about a log in the eye, referring to the role of some countries in unleashing World War II, came as a blow to the western neighbors' concept that is extremely important for their national identity. The leaders of Poland, who lost statehood as a result of the Hitler-Stalin conspiracy, can hardly be happy to be reminded of some 
not very nice episodes in the foreign policy of the second Polish-Lithuanian Commonwealth ahead of World War II.

So, the debate does not concern some abstract showdowns about "who is who" and who should try on the horns, and who should put on wings and a nimbus. We are talking about the founding principles underlying the existence of nations and countries. I do not mention short-term political goals, for this is the routine of historical politics.

In this case, I turn to purely rational arguments. However, historical politics and cultural memory do not always fit into rational schemes. Some themes and problems of the past retain powerful emotional potential, and words and actions can go beyond purely utilitarian considerations. If this potential is combined with utilitarian political considerations, you will get an explosive mix. It would be just enough to recall that appeals to history and "historical justice" have always been part of preparations for war and then became part of the war.

The current situation is largely reminiscent of previous aggravations, but now it is more than just a showdown between former allies in the socialist camp. The memory of the Holocaust is already a pan-European phenomenon, and its audience is growing rapidly, as are the opportunities to poke a finger in the part of the eye where the log is sitting, for example, by addressing certain circumstances of the Holocaust in Eastern Europe and the Baltic states. It should also be borne in mind that fifteen years ago the political situation was completely different: Europe was happy in its unification drive. Now "exits" have become a reality. Europe is disengaging, and some actors are tempted to help this process. Questions of the past come quite handy here.

Paradoxically, domestic politics becomes a continuation of foreign policy. Once engaged in historical battles with neighbors, states raise the interpretation of the past to the level of national security problems. The mobilization of historians for memory wars necessitates loyalty on the home front. Conflicts with neighbors over the past become an excuse for "tightening the screws" inside the country. The adoption of laws criminalizing the "misinterpretation" of the past or attempts to do so, as well as the expansion of competent agencies' jurisdiction to cover the interpretation of the past signal an extremely dangerous trend, which, as 
historical experience has always shown, impede society's ability to practice self-reflection and lead to the decay and collapse of political regimes.

And finally, there is a danger that this situation may reach a point where it will start to control itself and its creators: the latter will begin to act following the logic of events and the situation, rather than the logic of their plans and intentions. In fact, the excitement of confrontation with external and internal enemies is becoming almost the prevailing emotion. If it grows into collective enthusiasm for confrontation, negotiating will become much more difficult, if at all possible.

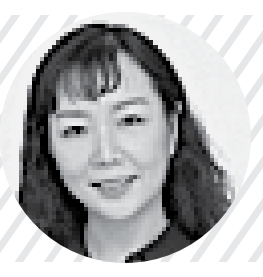

\section{Guo Xiaoli}

PhD in Philology, Professor,Deputy Director of the Institute of Foreign Languages, Hebei Normal University, China.

More than 70 years have passed since the international community unanimously recognized and hailed the Soviet Union's contribution to the victory in World War II. Its heroic fight against Nazi Germany is an unforgettable page in the history of the liberation anti-fascist war. In that war the USSR acted in two capacities: as an innocently suffering martyr and as a courageous savior. The Soviet Union not just saved itself, it also helped other peoples (not only China in the east, but also Poland), and together with other countries freed Europe from fascism. Those who try to distort historical facts and pick fragments to create "a new version" of history must be ashamed. A fictional "version" will not get the support of the international community. This is a closed question.

President Vladimir Putin has announced that Russia will create a complete archive of documents about the Second World War. We investigate history in order to confirm the authenticity of facts and restore the truth. One must not weave conspiracies and pass white as black, distorting the truth. Why is the truth important in political history? Because descendants must learn from the past in order to avoid new troubles so that humanity could go forward and make progress. In any case, it must not degrade. No one should distort history in order to deter Russia and exacerbate its isolation. 
At first glance, it seems that this is just a dispute between Poland and Russia, but in fact everyone knows that the United States stands behind Poland. The United States is rocking the situation, trying to make Poland a Trojan horse in Europe. Why is the United States attacking Russia despite universal condemnation? They believe that Russia prevents the spread of "democratic" values as Americans understand them. They are afraid of losing the status of a great power in the international arena and trying to provoke a split between Europe and Russia. We can all see that the image of the United States is going downhill, while Russia's influence in the international arena is on the rise, especially in the Middle East. There is a Chinese proverb saying that if a tree rises above the forest, a strong wind will certainly try to bend it.

Why have some Slavic peoples happened to be at the forefront of Russophobia? In the 19th century, sociologist and pan-Slavist Nikolai Danilevsky expressed the opinion that the Slavic peoples should in the future form and develop their own cultural and historical type because they are genetically close in terms of ethnicity and language. But we do not yet see the possibility of such a future. For several centuries, Poland and Russia have had a very complex relationship that resembles relations between China and Japan. We will not examine this historical problem here, but I would like to emphasize that relations between neighboring peoples are always the most difficult due to human nature. Fyodor Dostoevsky, who spent his life exploring human nature, rightly noted that a person could love someone at a distance, but it is difficult for him to love his neighbor. Indeed, people look favorably on the prosperity and success of a stranger, but cannot tolerate the same from a loved one. A conflict between neighbors is always acuter than between strangers. Perhaps Poland and Russia, China and Japan should think about this.

The history of China has recoded the following event: in the 230S AD, Prince $\mathrm{Cao} \mathrm{Pi}$, fighting for the throne of the ruler, wanted to kill his brother Cao Zhi who responded with the following verses:

Cooking beans on a fire of beanstalks,

The beans weep in the pot.

Born of the same roots,

Why the eagerness to destroy one another?

(Translated by J. Wong) 
Conflicts fueled by historical events lead to division and disunity. But it would be utterly wrong to invent a new version of history just because of differing interpretations of civil strife, for in so doing on can become a weapon in the hands of people with bad intentions. And yet some Eastern European countries have got bogged down trying to work out their own historical versions, while ignoring the global march of human history. We can see the world sort of splitting up into two camps: us and them (and if you are not one of us, you are a stranger). They are engaged in a struggle for life or death.

The classic Chinese novel "Three Kingdoms" begins with the following words: "The empire, long divided, must unite; long united, must divide. Thus it has ever been." We all saw that after World War II a centripetal trend prevailed in Europe-the creation of the European Union, but now there is a reverse process - the centrifugal force has taken over.

The threat of a new Cold War is felt not only in Asia and America, but also in Europe. This war is not like the previous one, because so much has changed in recent years: there are growing trends of division and discretization that contradict the convergence theory, the world has split up into the rich and the poor, new problems have popped up with the development of high technologies, extremist forces hold sway, the climate is deteriorating, and epidemics break out repeatedly... None of these problems can be solved by any one state alone. All peoples on Earth have a common destiny. All peoples and countries must unite, not because they love each other, but because they face common challenges that cannot be solved in isolation. We need dialogue and cooperation on the basis of competition.

In Russian culture, there is the term 'sobornost' (toghetherness), which academician and philosopher Andrei Smirnov expressed in an extra-religious language as "all-agency," meaning that every person is an interminable agency. In traditional Chinese culture there is a similar concept-'the harmony of diversity.' In such a picture of the world, there is no room for dividing countries into normal and abnormal, right and wrong, more developed and less developed; each nation and each country is unique in its own way.

World identity should mean respect for different cultures and political regimes, but not dominance and the imposition of "the only correct values." 
What makes our planet so wonderful is that all flowers bloom on it: the lily, the rose, the lotus, the dandelion, and the chamomile... And when lifethreatening crises hang over humanity, all states, including Russia, European countries (Eastern European ones among them), and China must come to a consensus, respect history and multiculturalism, and collectively solve urgent problems, rather than disengage.

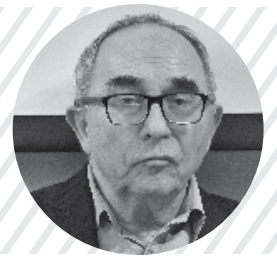

\section{Aleksander Smolar}

President of the Stefan Batory Foundation, Poland.

In Russia and Poland, there is a fear of changing narratives about their role in the Second World War. The official versions of both historical memories are in violent conflict.

Let us start with my country-Poland. Since the fall of communism in 1989 the Polish perception of the Second World War has been simple: Poland was occupied on September 1, 1939 by German forces which were joined on September 17, 1939 by the Red Army. The new partition of Poland-in reference to the 18th-century partition among the three empires: Russia, Germany, and Austro-Hungary-was the result of the Molotov-Ribbentrop Pact signed on August 23, 1939. During the war, six million Polish citizens were killed, and hundreds of thousands were sent to Siberia. The murder of more than 20,000 Polish officers by the Soviet forces in Katyn is inscribed in Polish memory. Poles speak about the liberation of Auschwitz but never about the liberation of Warsaw. The Red Army did not cross the Vistula River until the Warsaw uprising was crashed by the Germans and 200,000 Poles were killed. Poles do not even use a more justified formula-the liberation of Poland from Nazi occupation in 1945-because the new regime was imposed upon Poland by Moscow.

The Polish perception of the war is tragic and heroic, and both adjectives are justified. Russian President Putin's recent presentation of WWII with a major and negative role attributed to Poland was quite surprising, and that 
is an understatement. But there are two problems with the Polish narrative. First, a minor problem. Poland took advantage of the Munich Agreement and of the German occupation of Czechoslovakia to occupy a small part of its territory around Cieszyn. Poland was not a Nazi partner but played a very bad role by taking advantage of the Nazi invasion.

The second problem is more important and dramatic for Polish memory and self-perception. Poland was an innocent victim of Germany, of the Soviet Union, and even of Ukraine, where nationalists in Volhynia massively murdered Poles. The only moral problem the Polish national consciousness cannot easily solve is the problem of Jews. In 1941 there were many pogroms of Jews and in fact after the war, as well. During the war, there was denunciation of Jews, blackmailing, etc. There were also many Poles who helped Jews, but in Jewish memory the negative image of Polish behavior prevails.

Poland's New Holocaust Law passed in March 2018 was a stupid response of the Polish nationalist and populist authorities. Attributing responsibility for the Holocaust or complicity to the Polish nation or state was made illegal by this law. It caused a wide international reaction, accusing Poland of an attempt to whitewash unpleasant parts of its history. The Polish government had to backtrack by removing the threat of jail sentence from the law.

What about Russia? Those who rule Russia today see Europe's dominant narrative of WWII shifting against Russia. The European Parliament's resolution of September 2019 that equates the Soviet regime with the Nazi one is a significant fact from this point of view. The shift of the narrative is perceived in Russia and in the West as the result of Eastern Europe's increasing role on the continent as a whole. Poland and the Baltic states certainly play an important role in it.

Recently, President Putin on many occasions-at a meeting with other post-Soviet leaders, during his big end-of-year press conference, and at a meeting with top generals in the Ministry of Defense-put forward accusations against Poland regarding its role in WWII. Apparently, President Putin and his advisers believe that the countries of Central Europe, and particularly Poland, played an important role in modifying Russia's image and the Soviet Union's role in WWII. This seems to be dangerous for domestic reasons: "Velikaya Otechestvennaya voina" (Great Patriotic War) is an 
important source of legitimacy of post-Soviet Russia. It is also an important factor in legitimizing Russia's global role today. It was not accidental that during recent commemorative events in Jerusalem Vladimir Putin proposed convening a conference of the permanent members of the UN Security Council.

In this year's first issue of Rossiya $v$ Globalnoi Politike we can find an explanation of the surprising attack against Poland by Moscow (Rossiya, 2020). Historian Fyodor Gaida clearly explains the tactic: "So then our main scapegoat is Poland. If the European bureaucrats and we need a common enemy, I guess Poland will be the first candidate. Poland's role should get the most attention, which is what is happening today."

I do not think it is realistic to expect the formation of an alliance of Russia and the West in the memory war against Poland. Democratic culture is based, among other things, on the ability to integrate positive and negative facts about the community and its past. I can see certain progress in this respect, though quite limited on the Polish side.

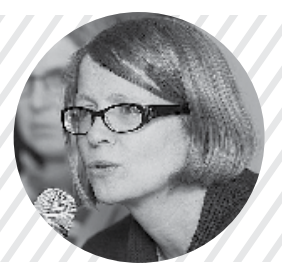

\section{Anke Hilbrenner}

Professor at the University of Göttingen, Germany.

Memory politics has always been important. But today we are experiencing a fierce struggle for the memory of the Second World War. The last major turning point in memory politics took place in the late 1980s. In Germany, the public debate called "Historikerstreit" centered around the singularity of German guilt for the war crimes committed during the Second World War, while in the Soviet Union, with a new openness (glasnost), the existence of the secret additional protocol to the Hitler-Stalin pact and the truth about the Katyn massacre were addressed. A little later, with the end of the Soviet Union and the overcoming of the German division, as well as with the democracy movement in Eastern and Central Europe, a paradigm shift in the realm of (real) politics followed.

After about 30 years of relative calm in the largely consensus-oriented European politics of remembrance of the Second World War, there is again an 
uproar. Does this historical-political unrest once again go hand in hand with a political upheaval? What are the reasons for the fact that the European consensus is being denounced by several sides? One reason for this "new" politics of history is the return to the concept of 'nation,' which for many has replaced European or other concepts of belonging. Right-wing or socalled "national" political forces, such as the AFD in Germany, deliberately break with traditional conventions of remembrance of the Second World War. In Eastern and Central Europe, in Hungary, and in Poland, the nation is increasingly being played off against other offers of identity. The current Polish government branded the memory politics of its predecessors, such as the transnational concept of the Museum of the Second World War in Gdansk, as "post-modern" and arbitrary. Instead, what is demanded is a narrative of sacrifice, to which the Polish nation can also refer today, in the face of current adversity. Polyphony of the historical discourse and the enabling of several perspectives are no longer desired. And Poland is not alone in this. Liberal memory politics is currently under scrutiny in several countries.

National memory narratives are mutually exclusive. In the simple logic of the perpetrator and the victim, there is only one option for one's own national memory community: the respective national histories are used as weapons against each other in the present, one's own nation is the victim, the other nation is collectively declared the perpetrator. But in Poland, Russia, and Ukraine, there were both victims and perpetratorsand sometimes people were both at the same time. Because the Germans, with their murderous war of annihilation, not only claimed millions of victims and thus created (of course, unwillingly) martyrs and heroes, but they also created the conditions for taking advantage and corruption, as well as an existential need, from which often only the strongest and most unscrupulous found a way out at the expense of the others. The collapse of statehood in the "blood lands" launched old conflicts and new violence, while the weak were without protection. The fact that the Germans are to blame for the historically singular crime of the Holocaust, as well as for the unleashing of the Second World War with its monstrous war crimes, does not mean that the people of Eastern and Central Europe did not also suffer under Stalinism. Many suffered under both systems, and their interaction exacerbated their suffering. The war criminals on all sides did not stop at 
the respective national borders, which were not stable at that time. The memory of the Second World War must face up to this tragic realization; only then can a narrative be created that is valid across national borders.

Historians know all this. It is the politicians who often use history. This use of history for the "national" cause is not harmless. It prevents the understanding of each other, who in this way quickly become political and ideological opponents, even though they share so many common experiences, such as the experience of marginalization, for example, or the fear of globalization and the dissolution of one's own values. The nation cannot be a solution to this, even if it is tempting to retreat into it. The idea of the nation already showed in the 20th century how dangerous its exclusive and particular interests can be in a modern and interconnected world. In the 21st century these teachings are even more valid.

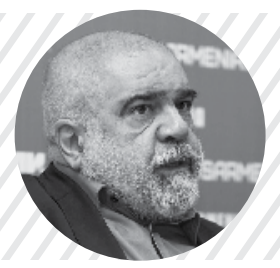

Alexander Iskandaryan

Founding Director of the Caucasus Institute, Yerevan, Armenia.

The recent outbreak of "memory wars" and the political instrumentalization of the past are not new phenomena. From the very beginning of the modern period, popular history, along with language, has served as building material for identities. But this phenomenon has almost nothing to do with historical science; rather, it can be studied using methods employed in political science. The purpose of popular history is not to understand or study the past, but to use the past for political confrontation. Positions and conclusions are not determined by the results of historical studies but are set in advance. Political actors use political tools to legitimize and subsequently instrumentalize a certain version of history. This is an important resource for politicians, because, among other things, antagonistic memory serves to mobilize "us" against "them." Goals are set, of course, within the framework of current policy, rather than historical science.

Naturally, this political technology - the use of ideas about historical memory for constructing one's own truth-is employed especially often 
when a country or community actively builds its identity. Such a need arises, for example, in newly formed states or when a new paradigm of state development is adopted, when a country changes enemies and/or friends and brings its historical narratives into line with political conditions. The more conflicting relations between countries (sometimes blocs of countries), the greater the need to substantiate the causes of a conflict, and this is where history comes handy. Modern conflicts are reverted into the past. Sometimes contradictions between modern states are declared primordial, in the spirit of the 19th century.

For example, the struggle for the recognition of the Armenian genocide in the Ottoman Empire is political in nature. There are no disagreements among historians over the events of the early 20th century-there are enough sources telling of them; differences concern only secondary details. However, politicians do not seek truth, but use the genocide to solve current problems. Countries that are not ready to recognize the genocide do not hide the fact that it is not about history, but political situation. In Turkey, this issue is regulated by the criminal code, which has an article imposing penalties "for insulting Turkey, the Turkish nation or Turkish government institutions," according to which, for example, writer Orhan Pamuk was accused of mentioning genocide. Another example is the Caucasus, where "memory wars" are fit into the context of ethnopolitical conflicts. The parties to a conflict intentionally build historical narratives that demonize the enemy. Moreover, it can be argued that hostile narratives are the result of political conflicts, not their cause.

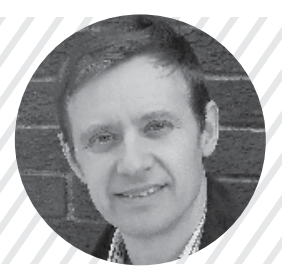

Paul Robinson

Professor at the Graduate School of Public and International Affairs, University of Ottawa, Canada.

History is a political tool. It is through references to the past that we legitimize or delegitimize our political and social systems. It is no surprise, therefore, that different groups compete to control their society's historical memory. Where competing narratives are incompatible, this competition can 
be quite bitter in nature, as can be seen, for instance, in the dispute in the American south over Confederate monuments, and by that in Ukraine over the Second World War.

The logical way to resolve such issues is through objective historical research (insofar as such a thing is possible). In the 1980s, there were sharp disagreements among historians about the number of victims of Stalin's Great Terror. In the context of the Cold War, some historians regarded it as important to keep the numbers high in order to delegitimize the Soviet Union, and so resisted attempts to revise the numbers downwards. In the end, however, the dispute was settled in favor of the revisionists. For once the Soviet archives were opened, it became possible to adjudicate the dispute on the grounds of evidence rather than politics.

Unfortunately, the power of history is such that politicians are all too often not content to leave it to the historians. This can be seen, for instance, in legislation passed in various countries declaring certain atrocities to be "genocide" (for instance the Ukrainian Holodomor). The selective nature of such declarations, as well as the often disputable nature of the judgements, point to these being essentially political statements, designed to enforce one form of historical memory over another.

Inevitably, the political nature of such acts is evident to those who feel that their own historical memory is being traduced. Politicized historical memory thus often backfires. This is true on the international as well as the national levels. As Robert Jervis has pointed out, states often fail to realize that other states perceive the world differently. This applies to the field of historical memory as much as any other, as we can see in the recent argument between Poland and the Russian Federation about the Second World War. The Poles' belief that the Soviets, in liberating them from the Nazis, subjected them to a new form of occupation is perceived by Russians as an attack on the legitimacy of the Russian Federation. But the Russians' insistence that the Soviets were liberators, not occupiers, is perceived in Poland as proof of unwillingness to repent of past sins, and thus also as an indicator of possible future aggression. The more each side insists on its righteousness, the less it convinces the other.

Disputes over historical memory are part and parcel of political competition. It is no surprise, therefore, that the debate about the Soviet 
Union's role in the Second World War should have become so sharp at a time of rising East-West tension. When that tension subsides, the historical disputes will probably become less tense too. In this sense, they are perhaps more a symptom than they are a cause of conflict.

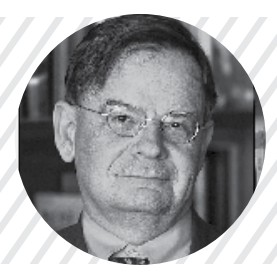

\section{Andrei Lankov}

Professor, Kookmin University,

Seoul, Republic of Korea.

There is no concept of 'memory war' in the Korean language, but in Korean historiography memory wars began when this notion did not yet exit in other languages either. In general, this phenomenon is characteristic of the entire Far East. It is probably associated with some features of Confucian culture. In Europe, the traditional perception of international relations is somewhat identical to a relationship between two noble men, each of whom can opt either for an allied or hostile relationship - up to a deadly feudwith the other. This tradition, enshrined in the Westphalian "world order," remained in force until the 1920 s, when it began to be ousted by somewhat hypocritical discource about the inadmissibility of aggression, sometimes barely connected with reality.

In East Asia, the situation is different. It is traditionally believed there that moral and right people do not conflict with each other. And if a conflict breaks out, then it is to be blamed on the "wrong" and "immoral" side. This also applies to relations between states, of course. Hence constant attempts to prove that a conflict is caused not by a clash of rational interests, but, relatively speaking, by forces of good and evil, not in the biblical sense, of course, but in the sense of morality and immorality.

Different countries of the Far East build their memory politics differently. In China, for example, it is largely determined by the CPC Central Committee. In South Korea, this is done much more often (although not always) by the public, and in many cases against the will of the government. This makes it very difficult for the authorities to challenge the ideology adopted by the progressive public led by opinion leaders: intellectuals and academics. 
At the same time, memory wars are waged at the highest level and involve government officials, including heads of state who rebuke, cut down to size, talk of the unhealing wounds of their nations and terrible crimes of the neighbors. These wars (often fought over events of a very distant past) have reached such proportions in the Far East lately that they astonish even European observers, who are very well aware that there has always been room for moralization and politicization in history.

But Asian politicians do not consider this something special. Each new squabble is a nuisance, of course, but in any case the blame is unequivocally placed on the opponent. For example, the Japanese do not repent for their sins sincerely enough, so they have to be reproached for these sins over and over again; or the Vietnamese do not fully realize how much they owe to China, so they need to be constantly reminded of this. The main problem is ungratefulness or unwillingness to recognize one's past mistakes.

Such verbal tussles sometimes go beyond purely rhetorical swordplays, causing real political damage. Just recently another such "spat" put an agreement on the exchange of intelligence between Japan and South Korea at risk. At some point it seemed that very serious arrangements concerning strategic security would be upset by the bickering over events of 70 years ago. In the end the top officials of the two states backed down and apologized to each other, having shown strategic restraint. But this is not always the case.

A hyped-up conflict is not so easy to stop even in authoritarian countires-or call them "lacking democratic traditions," if you like-such as China. Popular feelings that get out of hand can be a serious problem for the government that wants to defuse tension and take emotions under control. When a significant part of the population works itself up in a blaze of patriotic fervour, it can be difficult to put things into reverse. This has happened in China during occasional outbursts of anti-Japanese or antiAmerican sentiment, and in South Korea.

Strange as it may seem, but it is Japan that is least prone to memory wars now. Rather, it is more often their victim, largely because, as a rule, it reacted quite calmly to such attacks before, eventually turning into a punching bag for the countries of the region. There is a reason for that, of 
course: the aggressive policy Japan pursued in the past. But the importance of objective factors should not be overestimated in such a subjective matter as memory wars.

Until the 1990s, the Japanese political class was inclined to "pay and repent." However, over the past 15-20 years, it has come to realize that this approach is completely futile, since neither repentance nor compensation will solve the problem and it will arise again after some time. So the Japanese no longer want to play these games any more.

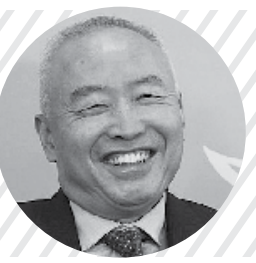

\section{Lanxin Xian}

Professor, International History and Politics, the Graduate Institute of International and Development Studies, Geneva, Switzerland.

How to read history is crucial in interpreting the nature of the U.S.- China relations. Trump administration officials blame China for its own internal problems, claiming that China is not grateful for all the good deeds the U.S. has done for the country. Vice President Mike Pence stated on October 4, 2018: "When China suffered through indignities and exploitations during her so-called 'Century of Humiliation,' America refused to join in, and advocated the 'Open Door' policy, so that we could have freer trade with China, and preserve their sovereignty." Such an argument gives the impression that the relationship has always been a one-way charity act, and the U.S. has never benefited from the extraterritorial rights and China's economic growth in history. Idealogues like Pence or Pompeo, of course, care nothing about historical facts.

Blaming others for one's own problems is a typical diversionary tactic that has been used by politicians since ancient times. It usually involves deploying some combination of half-truths, inaccurate data and distorted facts. In the last century, Adolf Hitler blamed the Treaty of Versailles for Germany's domestic problems. But not only are the American “Dragon Slayers" wrong in their reading of history, but they also must be held morally accountable for providing an answer to what other option the world had when China first opened up to the West: had China's economic 
development been nipped in the bud, the uplifting of hundreds of millions of people out of absolute poverty would never have taken place. They must provide evidence that all of China's gains have been made by breaking the rules. America's real problem is not that it does not work like China. It is that it no longer works like America.

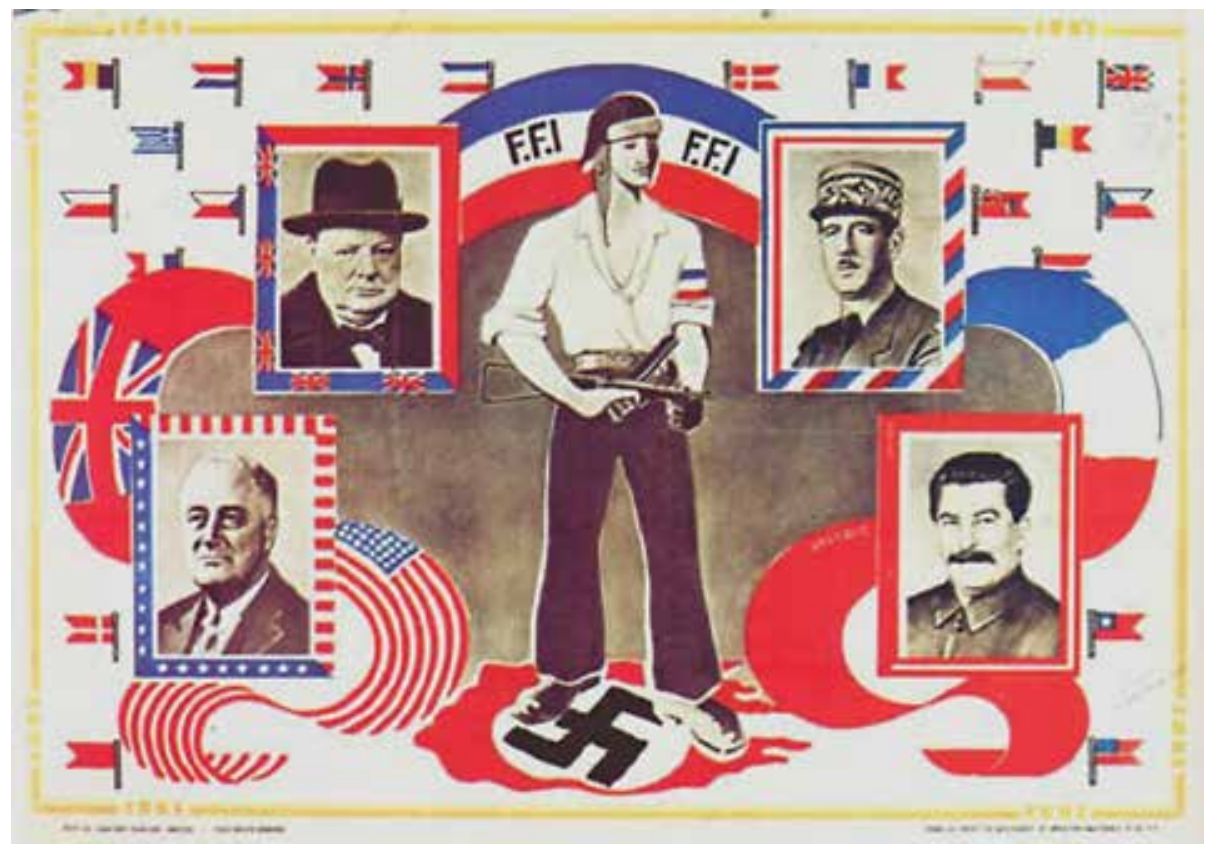




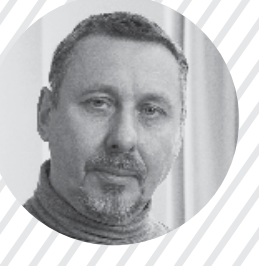

Alexei Miller

Professor at the Department of History of the European

University at St. Petersburg; Academic Supervisor of the

Center for the Study of Cultural Memory and Symbolic

Politics, St. Petersburg, Russia.

A fantastically interesting and broad-ranging collection of musings by intellectuals from different countries about the political use of the past in the modern world shows that all of them or almost all of them see an increased political use of the past in international relations. Most of them find the term 'memory wars' quite appropriate for describing the current state of affairs.

There is a noticeable spread of views on where the frontlines of these wars pass. Many tend to see the main line of confrontation in relations between Russia and Eastern Europe. Others point out quite rightly that this war is going on within the European Union as well. At stake in this confrontation is not only Russia's right to have a say in European affairs, but also the conflict of different cultural approaches to work with the past between the "old" and "new" Europe. "Critical patriotism" is losing the battle to the ethnization of history and narratives about one's own nation as solely a victim of history that dominate in Eastern Europe today. But it would be a mistake to see Europe as the only theater of these battles. They are also underway in Asia, albeit with obvious local specifics. The U.S. is engaged in them on different fronts as well. The legitimacy of Western claims to a leading role in the world and moral superiority, the legitimacy of liberal democracy as the "best" of all possible socio-political regimes is on the line.

The "affective management of history" is increasingly characteristic not only of international relations, but also of identity politics within national communities, as well as during the institutionalization of new groups claiming special rights as compensation for the "past suffering and oppression."

Interpretations of World War II have recently served as a breeding ground of this confrontation. There are many things in the history of World War II and in the treatment of those events that have not received 
due attention and proper critical assessment. But does the modern memory war bring us any closer to the truth, integral truth that includes both what we are used to be proud of and what we should be ashamed of? In war, as in war: there are only "us" and "them," only the parties to a conflict, with no room for the "on the one hand... but on the other hand" principle. We are victims, and they are the perpetrators. By having entered this war, we have deprived ourselves of the opportunity to deal with these spaces of omission and distortion. Instead, we are creating new ones. No one will win such a war, but we have already lost in it the trust that has gradually been built for decades, and the possibility of taking a self-critical look at the past.

The stakes in contemporary "memory wars" are very high, and these stakes are not so much about who will win tactical "victories" on which front, as about how big our common moral losses will be.

\section{References}

Rossiya, 2020. Istoricheskaya pamyat' - eshcho odno prostranstvo, gde reshayutsa politicheskie zadachi [Historical Memory Is Yet Another Space for Politicking]. Rossiya $v$ global'noi politike, 18(1) [online]. Available at: <globalaffairs.ru/articles/istoricheskaya-pamyat-eshhe-odno-prostranstvogde-reshayutsya-politicheskie-zadachi-2/>.

Resolution, 2019. Importance of European Remembrance for the Future of Europe. European Parliament Resolution as of 19 September 2019 [online]. Available at: <www.europarl.europa.eu/doceo/document/TA-9-2019-0021_ EN.html>.

Putin, V., 2019. Address at the CIS Informal Summit, St.-Petersburg, 20 December [online]. Available at: <en.kremlin.ru/events/president/news/62376>.

Radchenko, S., 2020. Vladimir Putin Wants to Rewrite the History of World War II. Foreign Policy, January 21, [online]. Available at: <foreignpolicy. com/2020/01/21/vladimir-putin-wants-to-rewrite-the-history-of-world-war$\mathrm{ii} />$.

Desai, D., 2020. Putin Is 'Cherrypicking' Facts When He Blames Poland for Helping to Start WWII, historians say. National Post, January 23 [online]. Available at: <https://nationalpost.com/news/world/its-a-blame-game-putin- 
speech-pointing-finger-at-poland-for-second-world-war-is-cherry-picking-sayexperts>.

Kolstø, P., 2019. Dmitry Medvedev's Commission Against the Falsification of History: Why Was It Created and What Did It Achieve? A Reassessment. The Slavonic and East European Review, 97(4), October. D0I: 10.5699/ slaveasteurorev2.97.4.0738.

V0Anews, 2015. V-Day in Russia Evokes National Pride at Difficult Time. VoiceOfAmerica News, May 07 [online]. Available at: <https://www.voanews. com/europe/v-day-russia-evokes-national-pride-difficult-time>. 